TECHNICAL TRANSACTIONS 8/2018

ARCHITECTURE AND URBAN PLANNING

DOI: $10.4467 / 2353737$ XCT.18.113.8888 SUBMISSION OF THE FINAL VERSION: 10/07/2018

\author{
Agnieszka Wójtowicz-Wróbel iD orcid.org/0000-0003-4087-395X \\ awojtowicz@pk.edu.pl \\ City Renewal Division, Institute of City and Regional Design, Faculty of Architecture, \\ Cracow University of Technology
}

\title{
SPATIAL SIGNIFICANCE OF NEW MUNICIPAL ENGINEERING STRUCTURES - THE CASE OF ITALIAN ECO-INCINERATION PLANTS
}

\section{ZNACZENIE PRZESTRZENNE NOWYCH OBIEKTÓW TECHNICZNEGO \\ ZAPLECZA MIAST - PRZYKŁAD W€OSKICH EKOSPALARNI}

\begin{abstract}
One of the indications of pro-environmental change is the construction of thermal waste processing plants, which occupy an excessive amount of space and are controversial structures in terms of public perception; however, they also create new potential possibilities for the areas in which they are placed. The objective of this study is to address the issue of the spatial significance of thermal waste processing plants from the points of view of accessibility, location and relations with the urban tissue; their architectural and visual significance within the environments they occupy is also considered. The study covered twelve Italian thermal waste processing plants located in varying spatial, economic and social conditions. The results of field analyses and the conclusions drawn from them can serve when conducting comparative studies of other structures of this type, both in Italy and further afield.
\end{abstract}

Keywords: thermal waste processing plants, industrial plants, pro-environmental structures, accessibility, industrial zones, metropolitan area, ecological city, eco-technology, circular economy

\section{Streszczenie}

Jednym ze znaków wspótczesnych proekologicznych przemian jest budowa zakładów termicznego przekształcania odpadów. Ekospalarnie, ze względu na swe gabaryty, mocno oddziaływają na przestrzeń, są obiektami kontrowersyjnymi w odbiorze społecznym, lecz także stwarzają potencjalnie nowe możliwości dla stref, w których są lokalizowane. Celem niniejszego artykułu jest znalezienie odpowiedzi na pytanie, jakie znaczenie przestrzenne mają zakłady termicznego przekształcania odpadów w trzech ujęciach: dostępności, lokalizacji i relacji z miejską tkanką, a także jakie jest ich znaczenie architektoniczne i wizualne w przestrzeni. Badaniami objęto ekospalarnie znajdujące się w różnych uwarunkowaniach przestrzennych, gospodarczych czy społecznych. Otrzymane wynikianalizterenowychiwyciagnięte naich podstawie wnioskimogą posłużyćpodczas prowadzenia badań porównawczych innych obiektów tego typu, zarówno na terenie Włoch, jak i poza granicami tego kraju. Słowa kluczowe: zakłady termicznego przekształcania odpadów, obiekty przemysłowe, obiekty proekologiczne, dostępność komunikacyjna, strefy przemysłowe, obszar metropolitalny, miasto ekologiczne 


\section{Introduction}

Increasing awareness of the necessity of protecting the natural environment sets new challenges before the residents of contemporary cities of the European Union, their authorities, as well as their designers. The necessity of protecting natural resources, ecosystems, as well as (or perhaps - from the point of view of the everyday life of a city resident - primarily) the necessity of reclaiming natural goods that have already been used by man is still a problem that becomes more and more topical. Awareness of increasing environmental pollution and of the exploitation of resources in a manner that is non-compliant with the precepts of sustainable development and the circulation economy generates two necessary actions that need to be taken in the public sphere:

- the ecological education of residents, right from the very start (pro-ecological kindergarten and primary-school-level education, etc.),

as well as:

- the adoption of pro-environmental stances on the matter of the protection of resources (e.g. raising the awareness of residents about the use of running water, et.c), as well as the reuse of resources (particularly focusing on the appropriate segregation of waste, so that only a very small amount will have to undergo thermal processing).

From the point of view of persons in charge of the management of cities, the rising problem of protecting natural heritage is also a manner of adapting municipal efforts to community policies which, on the one hand, introduce requirements concerning the adaptation of a city's economy, systems and legal documents, while on the other provide opportunities to benefit from European Union subsidies in terms of the protection of the environment and appropriate resource management. One of such possibilities is funding the construction of structures with new, pro-environmental functions from the European Union's budget. The construction of such structures is also a challenge to cities in social, economic and imagerelated (in the broader sense of the word) terms, as well as spatial ones. New possibilities of the development of pro-environmental technologies provide new opportunities, but also place new challenges before planners, urban designers and architects. Structures such as currently built thermal waste processing plants can and already are ecologically safe buildings. Following the examples set in other countries, municipal engineering structures do not need to focus solely on fulfilling a technical function, one that is associated with negative public reception. Currently built eco-incineration plants can be a challenge to an architect, urban designer and planner; in addition to constituting a social and spatial element, both from the architectural point of view, as well as in the field of spatial management.

This study is an extension of a research cycle of publications written by the author concerning structures with new pro-environmental functions within urban space. The author's research focuses on two groups of pro-environmental structures:

- thermal waste processing plants,

- wastewater treatment and water purification plants. 
The research is being performed with a focus on a group of five types of problems:

- the social sphere, with a particular focus on influence on the space of cities,

- the architectural sphere and the broadly understood beauty of structures,

- the sphere of placement and accessibility,

- the sphere of spatial relations and significance within the urban tissue, in addition to -

- technical and technological matters that can directly affect the spatial sphere.

Furthermore, the cycle is being supplemented by examples of good practice, as well as analyses of cases of pro-environmental efforts. This article is one of the examples of such analyses in reference to the urban structure.

\section{Thermal waste processing plants in Italy - an outline of the background and field of research}

Italy is one of those European countries that have faced the challenge of searching for a fast and effective solution to the management of an increasing amount of municipal waste, and which also had to find the answer to the question concerning the manner of the adaptation of contemporary municipal waste management in such a manner so that it can be compliant with European Union regulations $[1,3]$. The intensification of this problem was particularly observable in the first decade of the twenty-first century. At the time, the problem of the management of Italy's waste did not apply solely to municipal waste, but to - perhaps especially - industrial waste and its appropriate storage and neutralisation.

New forms of waste management started to be sought in the northern part of the country. This was a result of not only the necessity to process municipal waste, but primarily of the need to search for a solution to the problem of industrial waste with varying levels of threat to the environment. Simultaneously, in the southern and central parts, there arose the problem of depositing waste (including dangerous waste illegally buried as municipal waste) on landfills, as well as of the illegal depositing of waste on unauthorised waste dump sites, which were then being set aflame [2]. At the same time, the storage of dangerous materials in this manner caused a significant rise in soil, air and water pollution in agricultural areas, which constituted the basic source of income for many of the residents of those regions.

The lack of the possibility to deposit municipal waste in such cities like Naples (due to a lack of space in landfills), the aforementioned environmental pollution and failed attempts at solving this problem, like making decisions concerning the placement of new waste disposal sites in protected areas (e.g. in the national park at the foot of Mount Vesuvius), as well as the epidemiological threat associated with not removing waste from cities (e.g. from Naples) led to social and ecologically-based tensions [5]. One of the effects of the search for an effective solution to the problem of waste management was the construction of thermal waste processing plants. This was tied with both the redevelopment of existing incineration plants and the construction of new structures of this type in the spirit of environmentally-friendly solutions.

The redevelopment of existing plants was often a change focused not only on modernising their technology and adapting the architectural form of the structures themselves to new 
installation solutions. It included and still includes much broader measures: their extension, the introduction of a greater number of technological lines, the implementation of new ways of processing municipal waste, but also the introduction of the possibility of incinerating waste of a different type (industrial, RDF and other types), in addition to a fuller utilisation of the energy that is produced (connecting the plants to the municipal power grid, etc.).

Italy is one of those European Union member states that solve the problem of municipal waste with great intensity and we can clearly see the effects of measures taken in terms of municipal and regional policy in this field. Currently, there are 59 thermal waste processing plants in Italy [5] that produce energy used in municipal power grids. These are both incineration plants that process municipal solid waste, as well as those that process other types of it (RDF, industrial waste, etc.). It is noteworthy that over $54 \%$ of the structures that have been mentioned began operating after the year 2000.

According to the concept of the circulation economy [7], thermal waste processing is the final element in this field, employed only when all other possibilities of reusing a resource have been exhausted. From a technological standpoint, these are mostly installation utilising movable grate technology, which is currently the most widely used, and is seen as the most proven and reliable in current conditions [4]. Apart from this method, Italian incineration plants also utilise the gasification method or a mixed technology, which features one technological line processing waste using a movable grate, while the other uses gasification or a different method. Of note is also the fact that even in the case of mixed technologies, one line always utilises the proven movable grate technology [6].

\section{Scope and method of research}

From the perspective of the shaping of the city, new technologies of waste management lead to the necessity of searching for new spatial solutions. At the same time, structures serving this purpose are buildings with technological lines that are safe to the natural environment, friendly to their surroundings and create new possibilities of using the structures themselves. For this reason, their significance in the space of cities over the period of the past couple of decades has been significantly altered. They are structures that, apart from their basic role of waste processing, can feature other, additional functions, improving the attractiveness of the place in which they are located. However, when searching for the answer to the question concerning which of these structures can play a significant role within the urban tissue, it is important to determine their location, accessibility, as well as their visual significance as works of architecture.

In order to answer this question, twelve thermal waste processing plants in Italy were analysed. They are located in the areas surrounding the following localities: Acerra (near Naples), Arezzo, Bergamo, Bolzano, Brescia, Forli Casena, Gioia Tauro, Padua, Parma, Poggibonsi, Riccone near Rimini, as well as Trezzo sull'Adda. The group of structures that were analysed included both those that had been redeveloped (which in past decades had operated on the basis of environmentally unfriendly technologies, and that are currently adapted to 
contemporary standards of environmental protection, often expanded and architecturally transformed), as well as those which have been built in recent years as pro-environmental plants from the ground up.

The group includes both structures located in the northern part of Italy, which features intensive industrial development (e.g. Bolzano or Bergamo), as well as those located in the south (e.g. Acerra, near Naples) - a much less developed region of the country, which has in recent decades been troubled by problems of an ecological, economic and social nature. Both thermal waste processing plants which provide services to agricultural areas and the small towns located within them (e.g. Gioia Tauro) and those which focus on the processing of municipal solid waste of large urban centres like Naples or Milan were chosen for analysis. An overview of the placement of the analysed structures within the country has been presented in Fig. 1.

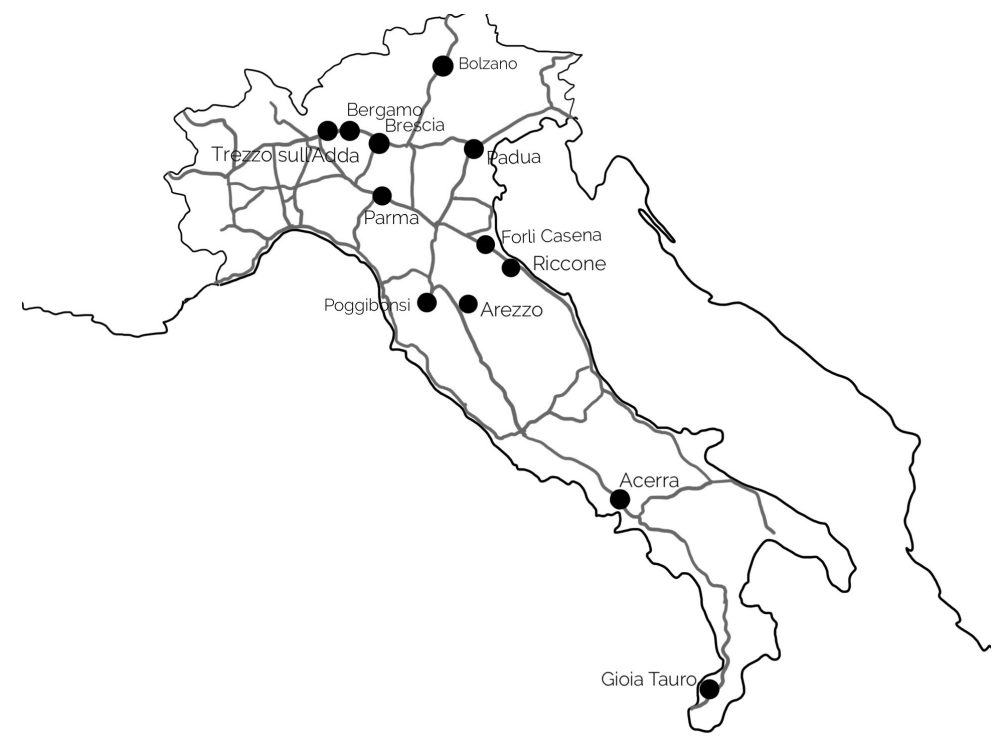

Fig. 1. Placement of the analysed thermal waste processing plants in Italy (original work, 2018)

The research that was performed focused on three groups of problems: the accessibility of the plants, their architectural attractiveness and visual significance within their surroundings, as well as their placement in relation to broadly understood urbanisation units.

\section{a) Accessibility}

Although the purposefulness of studying the problems of the placement of thermal waste processing plants within urban structures or the architectural qualities and visual impact of these types of structures on space appears to be obvious, the study of accessibility can raise some doubt as to their purposefulness. Eco-incineration plants are not public or commercial service buildings, which is why studying their accessibility - in the current situation - can raise some doubt. Accessibility, however, is a key element that conditions the possibility of the development of new functions, and in many of the studied structures such functions are either 
already present or are planned to be introduced in the immediate future. These are primarily functions associated with ecological education: from the organisation of educational paths to the planning of regular lectures, classes or courses, ranging from the level of primary education (classes for children promoting pro-environmental attitudes in everyday life) to specialist seminars or professional courses. In the case of such planned efforts accessibility or a lack thereof is a key element, significantly affecting the chances of the success of such endeavours.

The accessibility of the plants was measured in a number of ways: using an individual mode of transport (a car), public transport (which utilised various modes of transport depending on the city, in addition to using combined circulation), as well as the bicycle. The possibility of getting to the plants on foot was also investigated. A listing of the results of the research has been presented in table 1 .

A five-point rating scale was adopted during the measuring of accessibility, on which "A" signified the highest accessibility, while "E" the lowest accessibility. An additional mark signifying a lack of accessibility using a given mode of transport ("-”) has also been introduced. The isochrone was adapted to the given mode of travel each time, as well as to the hours during which the measurements were taken. In the case of the car and public transport, accessibility was measured at different time intervals - during the periods of the lowest and the highest loads being placed on the transport network.

Table 1. Accessibility of thermal waste processing plants

\begin{tabular}{|c|c|c|c|c|c|c|}
\hline \multirow{3}{*}{$\begin{array}{l}\text { Location of the } \\
\text { thermal waste } \\
\text { processing } \\
\text { plant }\end{array}$} & \multirow{2}{*}{\multicolumn{2}{|c|}{$\begin{array}{c}\text { Car } \\
\text { Accessibility (min.) } \\
\text { during the given traffic } \\
\text { load on the transport } \\
\text { network }\end{array}$}} & \multirow{2}{*}{\multicolumn{2}{|c|}{$\begin{array}{c}\text { Public transport } \\
\text { Accessibility (min.) } \\
\text { during the given traffic } \\
\text { load on the transport } \\
\text { network }\end{array}$}} & \multirow{3}{*}{$\begin{array}{l}\text { Accessibility } \\
\text { using a bicycle }\end{array}$} & \multirow{3}{*}{$\begin{array}{c}\text { Pedestrian } \\
\text { accessibility }\end{array}$} \\
\hline & & & & & & \\
\hline & Highest & Lowest & Highest & Lowest & & \\
\hline Acerra (Naples) & $A$ & $A$ & - & - & $B$ & $E$ \\
\hline Arezzo & $B$ & $B$ & $C$ & $D$ & $B$ & $E$ \\
\hline Bergamo & $A$ & $B$ & $B$ & $C$ & $C$ & E \\
\hline Bolzano & $A$ & $A$ & B & $D$ & $B$ & $E$ \\
\hline Brescia & $A$ & $A$ & $B$ & $C$ & $B$ & $E$ \\
\hline Forli Casena & $B$ & $A$ & $B$ & - & $B$ & E \\
\hline Gioia Tauro & $A$ & $A$ & - & - & $B$ & $E$ \\
\hline Padua & $B$ & $B$ & $B$ & $C$ & $B$ & $E$ \\
\hline Parma & $B$ & A & $D$ & - & $A$ & $E$ \\
\hline Poggibonsi & $A$ & $A$ & $A$ & - & $B$ & $E$ \\
\hline Riccone (Rimini) & $A$ & $A$ & $B$ & - & $A$ & $E$ \\
\hline Trezzo sull'Adda & $A$ & $A$ & $B$ & - & $A$ & $D$ \\
\hline
\end{tabular}

$\mathrm{A} / \mathrm{B} / \mathrm{C} / \mathrm{D} / \mathrm{E}$ - accessibility rating on a five-point scale, ranging from the highest $(\mathrm{A})$, to the lowest $(\mathrm{E})$

Tab.1. Accessibility of selected thermal waste processing plants in Italy (original work, 2018) 
In the first case, accessibility was measured in the morning (8:00-9:00) and afternoon (16:00-17:00) hours, during the time when commuting to and from work intensifies, while in the second case, the measurement was performed only once - between 24:00 and 01:00. The measurement was performed using the quickest possible route from a given plant to its city's main transfer node. This made it possible to compare the results of the analyses for numerous cities. For travel using a car during the greatest traffic load being placed on the circulation network, the following values for each isochrones were adopted, listed from the highest to the lowest accessibility: "A" (up to 15 minutes), "B" (15-30 minutes), "C" (30-45 minutes), "D" (45-60 minutes) and "E", with a travel time exceeding one hour.

At the same time, for measurements taken outside of rush hour, the following values were adopted: "A" (up to 10 minutes), "B" (10-20 minutes), "C" (20-30 minutes), "D” (30-45 minutes) and " $\mathrm{E}$ ", above 45 minutes. As it has been mentioned earlier, accessibility using public transport was also measured in two extreme periods of temporal accessibility, and in this case, a five-point rating scale was adopted using the same principle. Accessibility using the bicycle or pedestrian accessibility was measured once throughout the day, because the load placed on the circulation network had no effect on the results, for obvious reasons. A five-point scale was also used. In the case of travelling by bicycle, the isochrones were adopted as follows: "A" (up to 10 minutes), "B" (10-20 minutes), "C" (20-30 minutes), "D" (30-45 minutes) and "E", over 45 minutes. At the same time, pedestrian accessibility with a travel time of 5 minutes was considered the highest (A), within an interval of 5-10 minutes considered very good (B), 10-20 minutes was considered average (C), 20-30 was low (D), with very low being above 30 minutes (E).

\section{b) Location}

In order to determine the spatial relations that thermal waste processing plants either have or can have on the example of the analysed group of selected plants, an analysis of their surroundings was performed from an urban planning perspective. The research concerning the placement of the plants in relation to the more important elements of the urban tissue has been presented in table 2 .

Twelve thermal waste processing plants were subjected to an evaluation in relation to four types of elements of an urban structure: residential buildings, industrial buildings, commercial service buildings and their accessibility, as well as open areas. The analysis of the spatial relations with residential buildings was important mainly due to social concerns, as the placement of thermal waste processing plants close to housing areas is the subject that generates the greatest amount of emotions in the public eye. In the residential buildings group, the analysis focused on the placement of dense multi-family residential complexes (M1) and dense complexes of single-family houses. Loosely placed single-family building complexes were also listed (M3) ${ }^{1}$. Thermal waste processing plants located outside of housing areas were listed as well.

Eco-incineration plants were quite often placed in areas of an industrial character, which is why they were included in the analysis. The list includes placement inside an area (or directly

1 Loosely placed multi-family residential buildings were not present in the vicinity of any of the plants, which is why they have not been included in table 2 . 
Table 2. Placement of thermal waste processing plants

\begin{tabular}{|c|c|c|c|c|}
\hline $\begin{array}{c}\text { Location of thermal } \\
\text { municipal solid waste } \\
\text { processing plants }\end{array}$ & $\begin{array}{c}\text { Residential } \\
\text { buildings }\end{array}$ & $\begin{array}{c}\text { Industrial } \\
\text { buildings }\end{array}$ & $\begin{array}{c}\text { Commercial } \\
\text { service } \\
\text { buildings }\end{array}$ & Open areas \\
\hline Acerra (Naples) & $M 4$ & $P 1$ & $U 4$ & $O 4$ \\
\hline Arezzo & $M 3$ & $P 1$ & $U 2$ & $O 1$ \\
\hline Bergamo & $M 1, M 2$ & $P 1$ & $U 2, U 3$ & $O 3$ \\
\hline Bolzano & $M 4$ & $P 2$ & $U 2$ & $O 1$ \\
\hline Brescia & $M 1, M 2, M 3$ & $P 3$ & $U 3$ & $O 2$ \\
\hline Forli Casena & $M 3$ & $P 1$ & $U 2$ & $O 3$ \\
\hline Gioia Tauro & $M 3$ & $P 2$ & $U 4$ & $O 1$ \\
\hline Padua & $M 1, M 2$ & $P 1$ & $U 2$ & $O 3$ \\
\hline Parma & $M 4$ & $P 1$ & $U 1$ & $O 4$ \\
\hline Poggibonsi & $M 4$ & $P 1$ & $U 2, U 3$ & $O 2$ \\
\hline Riccone (Rimini) & $M 3$ & $P 1, P 2$ & $U 1$ & $O 2$ \\
\hline Trezzo sull'Adda & $M 1, M 2$ & $P 1$ & $U 2$ & $O 2$ \\
\hline
\end{tabular}

Due to the detailed description, the explanation of the individual symbols used in the table has been placed in the text. Tab.2. Placement of selected thermal waste processing plants in Italy (original work, 2018)

adjacent to one) of an intensively developing industrial zone (P1), in areas featuring individual buildings that do not form an industrial zone in urban-planning-related terms (P2), as well as outside of areas of an industrial character (P3). Table 2 also lists the accessibility of varying types of commercial services as an element which improves the attractiveness of a space. This group lists both different types of commercial services, the intensity of their presence, as well as the intensity of the spatial relations themselves. The placement of eco-incineration plants directly inside areas with commercial services ( $\mathrm{H} 1)$, in the vicinity of such areas $(\mathrm{H} 2)$, as well as in areas with a low presence of commercial buildings associated with industry $(\mathrm{H} 3)$ or housing (H4) has been listed. The final group (H5) includes those eco-incineration plants that were located outside of areas with immediate access to services. During the development of the research method, a listing for public services located in the immediate vicinity of thermal waste processing plants was present in the analysis, however, no such relations were observed in any of the twelve cities that were analysed.

In the group of analyses referring to relations with open areas, five possible marks were listed: three concerning the direct placement of a thermal waste processing plant and two referring to access to open areas in areas without direct access to them. Concerning plants located in the immediate vicinity of such areas, the list includes eco-incineration plants located within open areas (agricultural, woodland, other - O1), structures located in the immediate vicinity of built-up areas (industrial, residential, etc. - O2), as well as structures placed in open areas that are assigned for intensive development and expansion (e.g. of an industrial area - O4). In addition, 
the list also includes structures placed in places where open areas are located at a relatively close distance away (O3). Initially, the research was to take into account cases in which there were no open areas in the vicinity of the plants, however, the listing featured no such cases.

\section{c) Architecture and visual impact within a space}

Due to changes in technology and a greater awareness of the significance of proenvironmental structures, thermal waste processing plants are one of those sites, which have, over the past several decades, undergone considerable changes concerning their architectural form. This is particularly noticeable in the listing of buildings built over the last decade and of those buildings which were built in the second half of the previous century. The results of the research concerning aesthetic matters and the architectural evaluation of the buildings have been presented in table 3 .

Table 3. Evaluation of the visual significance and architectural qualities of thermal waste processing plants.

\begin{tabular}{|c|c|c|c|}
\hline $\begin{array}{c}\text { Location of the thermal waste } \\
\text { processing plants }\end{array}$ & $\begin{array}{l}\text { Architectural } \\
\text { qualities rating }\end{array}$ & $\begin{array}{c}\text { Visual significance } \\
\text { withiihn a space/ } \\
\text { impact }\end{array}$ & $\begin{array}{l}\text { Rating of the aesthetic } \\
\text { and compositional } \\
\text { qualities of the } \\
\text { development of the site }\end{array}$ \\
\hline Acerra (Naples) & $A$ & $B$ & $B$ \\
\hline Arezzo & $D$ & $B$ & $B$ \\
\hline Bergamo & $D$ & $B$ & $D$ \\
\hline Bolzano & $A$ & $A$ & $B$ \\
\hline Brescia & $B$ & $A$ & $A$ \\
\hline Forli Casena & C & $B$ & C \\
\hline Gioia Tauro & $E$ & C & $E$ \\
\hline Padua & $A$ & $A$ & C \\
\hline Parma & $A$ & $A$ & $A$ \\
\hline Poggibonsi & C & $E$ & $D$ \\
\hline Riccone (Rimini) & $A$ & C & $D$ \\
\hline Trezzo sull'Adda & $D$ & C & $D$ \\
\hline
\end{tabular}

$\mathrm{A} / \mathrm{B} / \mathrm{C} / \mathrm{D} / \mathrm{E}$ - visual significance and architectural qualities rating on a five-point scale, from the highest (A), to the lowest (E).

Tab. 3. Evaluation of the visual significance and architectural qualities of selected thermal waste processing plants in Italy (original work, 2018)

The analysis was conducted in three groups, referring to the different types of problems concerning the aesthetics of space. The architectural and compositional qualities of the plants' buildings were rated on a five-point scale, ranging from those of the highest quality (A), to those that featured a lack of aesthetic and compositional qualities (E). Due to the size of the thermal waste processing plants, an analysis of their visual significance in their surroundings, as well as of the impact of the buildings in both close and distant views was included as well. 
A five-point scale was analogously used to rate architectural qualities. The final element of the analysis presented in table 3 was the evaluation of the aesthetic and compositional qualities of the plants' site development. Elements taken into consideration included both the composition of the entirety of a building's surroundings within the borders of its site, its structuring, elements of streets furniture or the composition of greenery.

\section{Discussion and commentary on the results of the study}

The analysis of twelve thermal waste processing plants located in Italy provided a basis for the formulation of initial conclusions concerning the accessibility of such structures to city residents and others, the relations between eco-incineration plants and their surroundings within the area of the influence of cities of varying size, as well as for the rating of these types of plants from an architectural perspective. Based on the results that have been listed in table 1 , we can compare the accessibility of each structure while using various means of transport. Regardless of the amount of load placed on the transport network, accessibility by car was observed to be within the upper ratings. During the period of the highest load on the transport network, over $60 \%$ of the plants were observed to have the highest degree of accessibility (A), while the remaining had a very good degree (B). During the period of the lowest load being placed on the road network, the degree of accessibility was observed to increase and threequarters of all of the analysed structures noted the highest degree of accessibility.

A slightly lower accessibility was noted only in the case of three plants, located in Padua, Bergamo and Arezzo, but they nevertheless did have a relatively short travel time (B rating). When analysing travel time using public transport, it was observed that during rush hour over half of the plants were still accessible to a satisfactory degree, while in two cases this accessibility dropped significantly (Parma and Arezzo), while two plants were not accessible by public transport at all. These were Gioia Tauro, which is located far away from large cities, as well as the eco-incineration plant in the locality of Acerra, which is tasked with the incineration of solid waste from Naples, and which is also located in an area that is outside of the reach of public transport. Accessibility through public transport during the period of the lowest traffic intensity was observed to be highly limited due to the fact that the measurements were performed during night time.

Over half of the structures were unreachable during that time, as the areas in which they are located did not have public transport provided during those hours. Such access was provided to the remaining five structures, however, it varied between low accessibility ("C" rating - 3 plants) and very low accessibility (" $\mathrm{D}$ " rating -2 plants). Of note is the fact that there is no need for such plants to be accessible during night time, and the analysis of the travel time by car during nighttime hours (the same travel route) during the period of the lowest traffic intensity is proof enough of the potential that can be utilised in this regard. From among all of the categories of the analyses of the twelve thermal processing plants, pedestrian accessibility was rated the lowest. Only the eco-incineration plant located in Trezzo sull'Adda placed itself in the 20-30 minute isochrone (" $\mathrm{D}$ " rating). Travel on foot to all of the remaining plants took 
more than 30 minutes ("E" rating), while only the eco-incineration plant in Brescia found itself in the timeframe of between 30 and 40 minutes, while all of the remaining plants can be reached after an hour or one and a half an hour of walking.

When analysing the types of residential buildings located in the vicinity of the selected thermal waste processing plants, it was observed that a comparable amount of plants was located in the vicinity of dense complexes of multi-family and single-family residential buildings, as well as among loosely placed buildings, in addition to being outside of any and all housing areas. Simultaneously, more than one type of buildings was possible to identify in the vicinity of four of the plants - these were most often dense complexes of single and multifamily residential buildings (Bergamo, Padua and Trezzo sull'Adda), while in one case, apart from dense complexes of buildings of various types, there were also complexes of loosely placed single-family residential buildings (Brescia). The eco-incineration plant in Brescia was also the only plant located far away from industrial buildings. Three quarters of the analysed thermal waste processing plants were located in intensively developing industrial zones, while only three were located in areas with loosely placed individual structures of this character, out of which the eco-incineration plant in Riccone near Rimini was located at the border of two of the abovementioned types of areas (P1 and P2). Analyses of accessibility to commercial services and their various types which can increase the attractiveness of the area in which a given eco-incineration plant is located showed that two structures were located in areas outside of the range of access to any services whatsoever.

These include Gioia Tauro, which is located in a seaside area, close to an industrial and cargo port, as well as the newly-built eco-incineration plant in Acerra, which provides services to Naples. Services were observed to be located in the vicinity of the remaining plants, however, most of them were individual buildings associated with providing services to the industrial sector or a residential area located nearby, while in only two cases were there any dense commercial service complexes to speak of. These included the eco-incineration plant in Parma, which was located near a complex of big box stores, as well as the incineration plant near Rimini (Riccone), which, apart from the close proximity of retail buildings (the Raibano zone, Raibano I and Raibano II) was located close to a recreational area (aquapark, theme park, etc.).

When analysing the accessibility of various types of open areas and their placement relative to thermal waste processing plants, it was observed that the accessibility of such areas was shaped in the following manner: the largest group was formed by those structures which were located at the border between open and built-up areas. A slightly smaller group was formed by eco-incineration plants placed in open areas (agricultural areas, meadows or woodland), or those in which open areas were located relatively close by. Another group that was of no smaller size were those plants which were located near intensively developing industrial zones and the physical changes of the development of these areas will probably take place in the next couple of years. However, when analysing the set of the plants being discussed, we can generally observe that quantitative differences between each of the types $(\mathrm{O} 1, \mathrm{O} 2, \mathrm{O} 3$ and O4) listed in table 2 are insignificant, so any advantage in numbers in terms of the occurrence of some areas in relation to others would probably change after taking into consideration a larger group of cases, or if a different selection of such were performed. 
Aesthetic matters have been characterised in table 3 and were rated on a five-point scale in each of the groups. The evaluation of architectural qualities and values saw $50 \%$ of the plants rated either highly or very highly, while only one plant was rated as having no architectural values - being negative in its visual reception (Gioia Tauro - Fig.2).

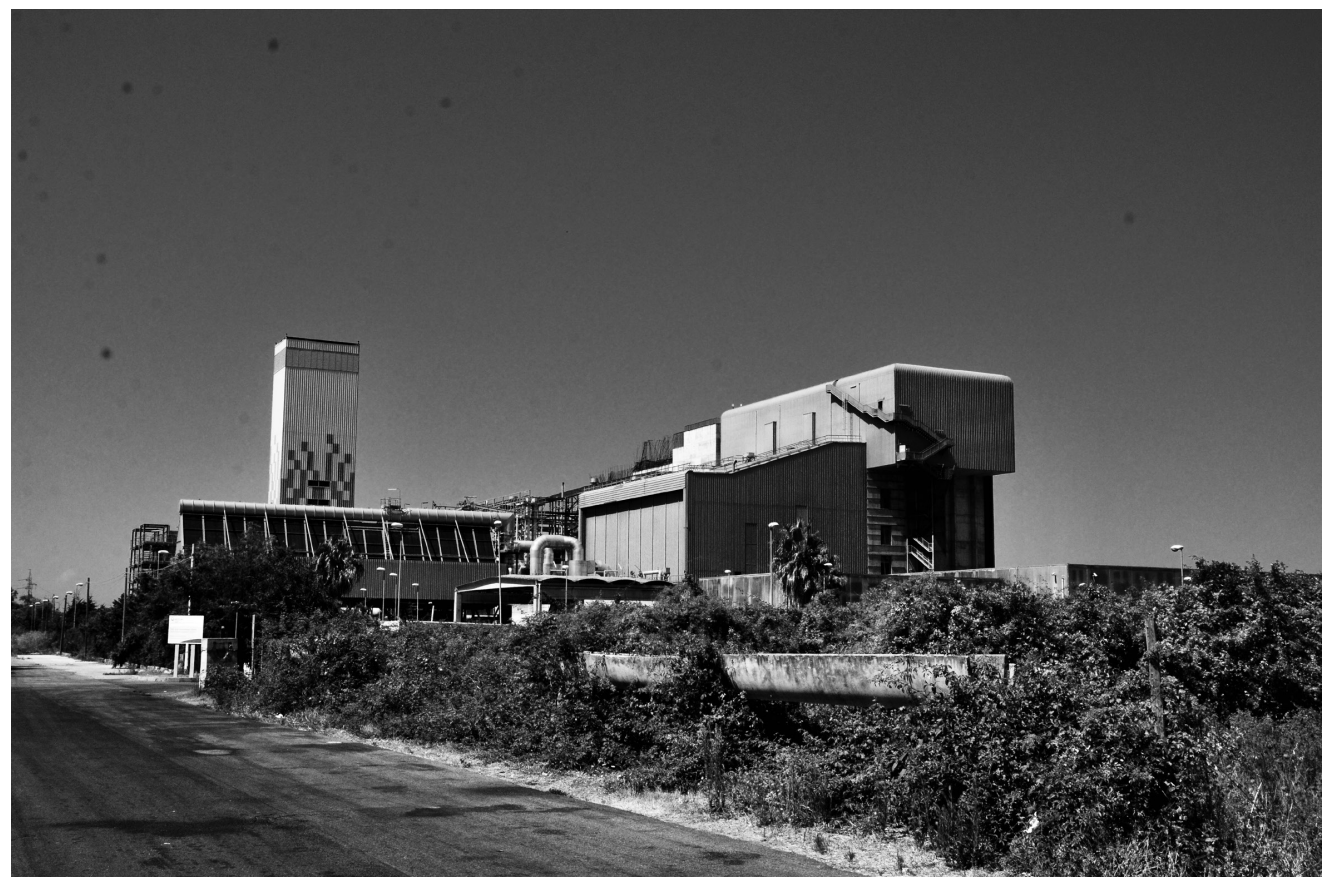

Fig. 2. Eco incineration plant - Gioia Tauro (original work, 2017)

The highest rated plants were those that were built in recent years, in the case of which there was a visible tendency for the shaping of the massings of the eco-incineration plants to not only constitute a form of an envelope for their technological solutions, but also attractive architectural forms. The spatial composition of the site on which a thermal waste processing plant was located was also an essential element. In five cases aesthetic and compositional qualities were rated very highly or highly and there was a visible correlation between the attractiveness of a structure's massing and care for its surroundings, although the dependency was not present in one hundred percent of cases. In some cases, the attractiveness of a building obtained the highest rating, while its surroundings were rated much lower.

One example of this was the eco-incineration plant in Riccone (Rimini-fig.3), where the plant possessed an attractive massing, with some elements constituting references to Italian architectural traditions (the envelopes of the smokestacks resembled campanile), while the surroundings of the plant were sorely lacking not only in compositional terms, but also concerning their structure. Due to their size, thermal waste processing plants can significantly affect their surroundings. From among the twelve plants, eight were rated as having a visual impact that was either significant or highly significant. Only one structure was rated as having an 
insignificant impact on its surroundings. It was the thermal waste processing plant in Poggibonsi, which was located in an area with terrain features and natural and landscape conditions that caused its visual significance to the surrounding space and its impact to be negligible.
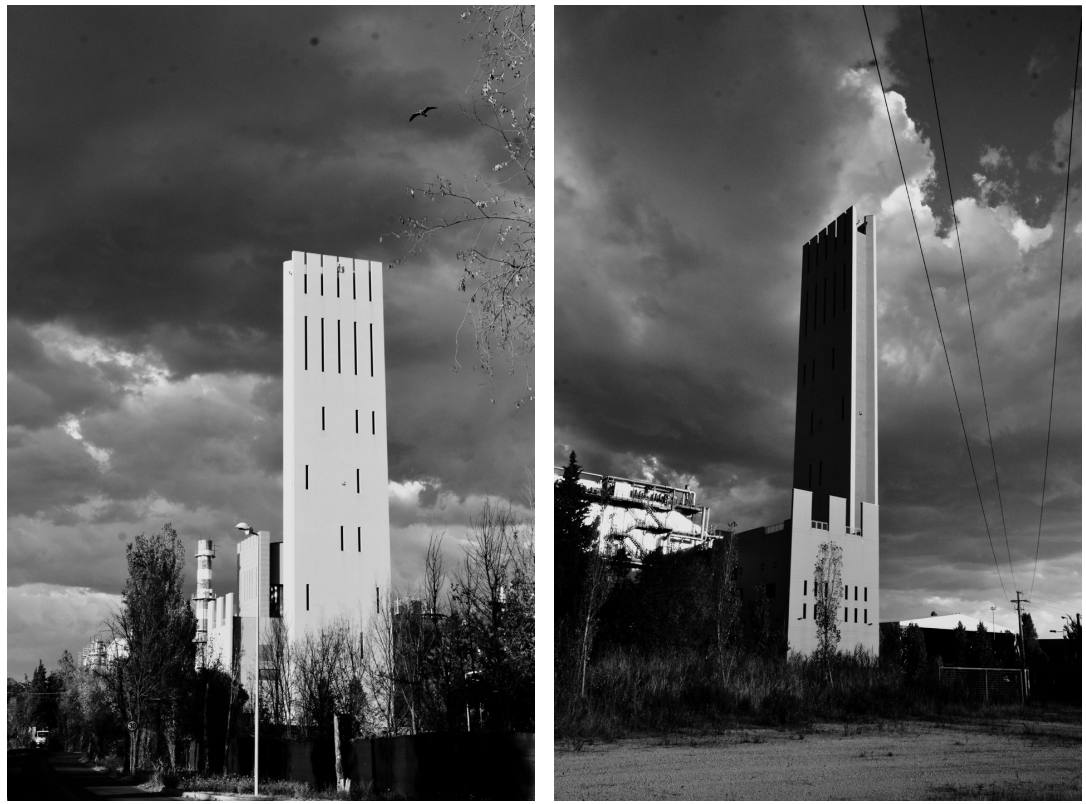

Fig. 3. Eco incineration plant - Riccone, near Rimini (photo by A. Wójtowicz-Wróbel, 2017)

\section{Summary and conclusions}

Italy is one of those countries which are undergoing a rapid and necessary change of the manner in which they manage waste towards an approach that is friendlier to the environment and compliant with the requirements of the European Union. Due to this fact, a selected group of structures - located in different spatial conditions and that were built in different periods, yet due to the same need - can prove an interesting field of study for other structures of this type. The analyses of selected thermal waste processing plants in Italy have made it possible to draw the following conclusions concerning three groups of problems:

- Accessibility: Good accessibility using an individual mode of transport is one of the constituents that provide an actual opportunity for the utilisation of the extent potential of thermal waste processing plants. At the same time, the condition that is necessary for these plants to be used for purposes other than their basic, technological ones, is - primarily - good accessibility through public transport (e.g. the possibility for potential attendees to come to a workshop or to use an educational path, etc.). Such accessibility was present in the cases that were discussed. Of note is also good accessibility using a bicycle, which, when coupled with placement in attractive open spaces, creates the opportunity to, for instance, use the structure as an essential element 
of urban or suburban bicycle trails (functionally - in the case of additional functions, or visually - as a landmark within the landscape).

- Location: A considerable majority of thermal waste processing plants is located either in or at the border of industrial areas. These are both dynamically developing and intensely built-up industrial areas, as well as those which are only starting to develop, resembling open areas with randomly placed buildings of an industrial character. At the same time, the vicinity of most eco-incineration plants includes residential buildings, ranging from dense multi-family residential complexes, complexes of row houses, etc. to individual houses either under construction or those that have already been built. It is most often the proximity of residential areas that causes the most controversy in the public eye and is the source of tensions of a social and ecological character.

- Architecture and visual impact: Due to their size, proportions and often also their location (e.g. near a bypass or a road entering the city) thermal waste processing plants are elements which have a strong spatial impact, which is why their architecture, as well as its appropriate highlighting (e.g. by nighttime illumination), is so essential. Placed in areas which are often lacking in terms of attractive architectural works, they can constitute the start of one of the variants of good patterns of designing industrialtype massings. Of note is the fact that structures designed after the start of the twentyfirst century were much more often designed as works of architecture, instead of only constituting physical envelopes of technological installations.

\section{References}

[1] Bukowski Z., Prawo ochrony środowiska w Unii Europejskiej, C.H.Beck, Warszawa 2007.

[2] Greyl L., Vegni S., Natalischio M., Cure S., Ferretti J., The Waste Crisis in Campania, Italy, www.ceecec.net/case-atudies/waste-crisis-in-campania-italy retrieved on2010 (access: 01.02.2018).

[3] Gwiazdowicz M., Sobolewski M., Ochrona środowiska w polityce UE, www.orka.sejm. gov.pl (access: 01.04.2018).

[4] Wielgosiński G., Przeglą technologii termicznego przekształcania odadów, [in:] Nowa Energia, ISS 1/2011, 2011.

[5] Wójtowicz-Wróbel A., From a vision to a necessity - from a necessity to a vision. Thermal waste processing plants - case study: Italy (article accepted for publication, [in:] IOP Conference Series: Materials Science and Engineering, (World Multidisciplinary Civil Engineering-Architecture-Urban Planning Symposium), Praha 2018.

[6] Waste - to - Energy. State of the Art. Report. Statistics, 6'th edition, International Solid Waste Association, 2012.

[7] European Commision - Environment - Circular Economy Strategy, http://ec.europa. eu/environment/circular-economy/index_en.htm (access: 01.03.2018). 